J. Dairy Sci. 95:6503-6512

http://dx.doi.org/10.3168/jds.2012-5643

(C) American Dairy Science Association ${ }^{\circledR}, 2012$.

\title{
The effect of incomplete milking or nursing on milk production, blood metabolites, and immune functions of dairy cows
}

\author{
E. Carbonneau, ${ }^{*}$ A. M. de Passillé, $†$ J. Rushen, † B. G. Talbot, ${ }^{\star}$ and P. Lacasse ${ }^{1}$ \\ *Département de Biologie, Faculté des Sciences, Université de Sherbrooke, Sherbrooke, QC, Canada, J1K 2R1 \\ †Pacific Agri-Food Research Centre, Agriculture and Agri-Food Canada, PO Box 1000, Agassiz, BC, Canada, V0M 1A0 \\ ‡Dairy and Swine Research and Development Centre, Agriculture and Agri-Food Canada, 2000 College, Sherbrooke, QC, Canada J1M 0C8
}

\begin{abstract}
During the transition from pregnancy to lactation, the sudden increase in nutrient demand for milk production causes metabolic perturbations and is associated with immunosuppression and a high incidence of metabolic and infectious diseases in high-yielding cows. In this study, we examined whether limiting milk harvest postpartum while maintaining milking stimulus could improve the metabolic status of cows without reducing overall milk production. Forty-seven Holstein cows were milked completely twice a day from calving (control); milked incompletely (about one-third of expected milk production was collected) twice a day until d 5 after calving (incomplete); or left to nurse their calf until d 5 and milked once a day from d 3 to d 5 (nursing). All cows were milked twice a day from d 6 to the end of the experiment (d 61). During the treatment period (d 1 to 5), milk production averaged 27.3 and $9.7 \mathrm{~kg} / \mathrm{d}$ for the control and incomplete treatments, respectively. We observed no residual effect of treatment on milk production, which averaged $47.8,45.7$, and $46.4 \mathrm{~kg} / \mathrm{d}$ for the control, incomplete, and nursing treatments, respectively, between wk 2 and 9 . The dry matter intake of the cows was similar during and after treatment. From wk 2 to 9 , milk protein and lactose percentage were not affected by treatments, but milk fat tended to be higher in control cows than in cows milked partially (incomplete + nursing). Blood concentrations of glucose and phosphorus were lower and concentrations of nonesterified fatty acids and $\beta$-hydroxybutyrate were higher in control cows than in partially milked cows during the treatment period. The positive effects on glucose and $\beta$-hydroxybutyrate remained significant up to d 28. Peripheral blood mononuclear cell (PBMC) proliferation and secretion of IL-4 were depressed during the postpartum period, and proliferation tended to be greater for cells incubated in serum from cows in the incomplete treatment on d 5 but lower on d 61 . We
\end{abstract}

Received April 19, 2012.

Accepted July 7, 2012

${ }^{1}$ Corresponding author: pierre.lacasse@agr.gc.ca observed no effect of treatments on polymorphonuclear neutrophilic leukocyte chemotaxis or phagocytosis. Proliferation and IL-4 secretion of PBMC were negatively correlated with concentration of serum nonesterified fatty acids. Reducing milk harvest postpartum while maintaining milking stimuli reduced metabolic stress without compromising productivity of high-yielding dairy cows.

Key words: $\beta$-hydroxybutyrate, immunosuppression, nonesterified fatty acids, transition period

\section{INTRODUCTION}

The periparturient or transition period of dairy cows is marked by nutritional, metabolic, hormonal, and immunological changes that affect the incidence of infections and metabolic diseases (Goff and Horst, 1997). During this period, cows are in a state of negative energy balance caused by a rapid increase in the demand for nutrients for milk production that exceeds the increase in food intake (Bauman and Currie, 1980). This results in lower blood glucose and mobilization of body reserves to provide additional energy, leading to elevated blood NEFA and BHBA (Drackley, 1999; Busato et al., 2002). In addition, calcium and phosphorus are mobilized for milk synthesis, leading to a decrease in their blood concentrations (Drackley et al., 2005). All of these metabolic changes can lead to hypocalcemia, ketosis, displaced abomasum, and hepatic lipidosis (Daniel, 1983; Goff and Horst, 1997; Bobe et al., 2004; Drackley et al., 2005; LeBlanc et al., 2005).

During the transition period, dairy cows experience a natural state of immunosuppression, which can increase their susceptibility to uterine and mammary infections (Kehrli et al., 1989a,b; Sheldon, 2004). Parturition is associated with a decrease in the number of PMNL (Kehrli et al., 1989a; Sheldon, 2004). In addition, neutrophils undergo a weakening of their phagocytosis capacity and a decrease in their ability to fight bacteria (Kehrli et al., 1989a). This period is also marked by decreased responsiveness of blood lymphocytes to stimulation with mitogenic agents and by decreased 
immunoglobulin production by B cells (Nonnecke et al., 2003). High NEFA concentrations have been associated with impaired lymphocyte proliferation and PMNL functions (Hammon et al., 2006; Ster et al., 2012). Therefore, strategies that prevent increases in blood NEFA during the transition period may limit postpartum immunosuppression.

Improving the energy balance in the immediate postpartum period should greatly reduce the incidence of periparturient disease in dairy cows. Accordingly, improvement of nutrient supply through periparturient nutritional management has been the subject of considerable research. However, another way to reduce the imbalance between nutrient supply and demand is to temporarily decrease the latter. Biological mechanisms exist that adjust milk secretion to the demand for milk. Thus, a reduction in milk production can be achieved by reducing the quantity of milk harvested. In an earlier study, a group of cows was milked once daily in their first week of lactation, and then twice daily, whereas a second group of cows was milked twice daily throughout lactation. The cows milked once a day showed an improvement in their metabolic profile (Loiselle et al., 2009) and immune function (Ster et al., 2012).

A disadvantage of milking once a day in early lactation, however, was that the milk production of cows milked once a day did not fully catch up with that of the cows milked twice daily, even after twice-daily milking was resumed (Loiselle et al., 2009). Milking and nursing induce releases of oxytocin, prolactin (PRL), and glucocorticoids into the cow's blood (Gorewit et al., 1992; Krohn, 2001; Lupoli et al., 2001). Nursing a calf leads to an increase in PRL concentration similar to that associated with milking, even if the amount of milk taken is much smaller (de Passillé et al., 2008). Although the basal concentration of PRL is not clearly associated with the level of milk production, PRL release induced by the act of milking is correlated with the level of milk production (Koprowski and Tucker, 1973), and inhibition of PRL secretion reduces milk production in dairy cows (Lacasse et al., 2011). Therefore, the aim of the present study was to test the hypotheses that reducing milk output through nursing or incomplete milking while maintaining frequent milk removal stimulus (1) ensures a milk production similar to that of a cow milked twice a day since calving when twice-daily milking is resumed, and (2) improves metabolic status and immune function.

\section{MATERIALS AND METHODS}

\section{Animals and Experimental Procedures}

The experiment was conducted from November 2009 to August 2010 at the University of British Columbia
Dairy Education and Research Centre (Agassiz, BC, Canada). All experimental conditions and procedures met the requirements of the Canadian Council on Animal Care (CCAC, 1993). Forty-seven multiparous Holstein cows balanced for previous lactation milk production and parity were assigned at calving to 1 of 3 treatments. Fifteen cows were milked completely twice a day $(0630$ and $1730 \mathrm{~h}$ ) for the $61 \mathrm{~d}$ of the experimental period (control, CON). Sixteen cows were incompletely milked twice a day $(6 \mathrm{~L}$ on $\mathrm{d} 1,8 \mathrm{~L}$ on d 2, $10 \mathrm{~L}$ on d $3,12 \mathrm{~L}$ on d 4, and $14 \mathrm{~L}$ on d 5) for the first $5 \mathrm{~d}$ and were milked completely for the rest of the experimental period (incomplete, INC). Sixteen cows were left with their calves for $5 \mathrm{~d}$ and were milked completely once daily in the morning $(0630 \mathrm{~h})$ on $\mathrm{d} 3$, 4 , and 5 after calving (nursing, NUR). Cows from the NUR treatment were milked completely twice a day for the rest of the experimental period (d 6 to 61 ; posttreatment period).

Calves from the NUR treatment received $4 \mathrm{~L}$ of frozen colostrum in the first $6 \mathrm{~h}$ after birth and received help to learn how to suckle the dam. Calves were left with the dam on d 6 and 7 for gradual separation but nursing was prevented by a nose ring. From calving until d 7, all cows were housed in individual maternity pens. Each maternity pen contained a feed bin and a water trough. Maternity pens were cleaned twice a day and new straw was added every day in the morning.

From d 8 until 61, cows were kept in freestall pens containing 9 animals. Each pen was equipped with sand bedding and with feed bins that measured intakes at each meal and water troughs (Insentec BV, Marknesse, the Netherlands), to ensure precise recording of feed and water intakes (Chapinal et al., 2007). From calving to d 61, cows were fed ad libitum with a TMR made with grass and alfalfa silages, and corn (CP 16.5\%, $\mathrm{ADF} 15.73 \%$, NDF $31.15 \%$, Ca $0.93 \%, \mathrm{P} 0.33 \%, \mathrm{Mg}$ $0.32 \%$, and $\mathrm{K} 1.58 \%$ ). Feed samples were taken every week, and the samples were pooled by groups at 4-wk intervals for composition analysis. Feed intake was recorded every day and cows were weighed on d 2, 8, 28, and 61 after parturition. Water intake was noted from d 8 to 61 . Milk production was recorded every day, except for the milk drunk by the calves of the NUR treatment group. Milk composition (fat, protein, lactose, and SCC) was evaluated once a week (composite sample from a.m. and p.m. milkings) by Pacific Milk Analysis Laboratory (Chilliwack, BC, Canada). Average DIM at first sampling was 3.6, 3.56, and 3.5 for CON, INC, and NUR cows, respectively. Blood samples were taken by jugular venipuncture around $0900 \mathrm{~h}$ on $\mathrm{d} 2,5$, and 61 and by tail venipuncture on $\mathrm{d}-21,3,4,14,21$, and 28 . Blood samples were collected in Vacutainer tubes (Becton Dickinson and Co., Rutherford, NJ) with and with- 
out EDTA to collect plasma and serum for metabolic and immunological assays. Blood smears were made on d 2, 5, and 61 to evaluate blood cell populations (True North Veterinary Diagnostics, Langley, BC, Canada). All health disorders and treatments were recorded.

\section{Metabolite Assays}

Serum BHBA was determined using the $\beta$-hydroxybutyrate reagent kit of Pointe Scientific Inc. (Canton, MI). Serum phosphorus was determined with a Phosphorus-SL Assay (Diagnostic Chemicals Ltd., Charlottetown, PEI, Canada). The manufacturers' protocols were modified for 96 -well plates by reducing the volume of reagents and samples. The absorbance measurements for these assays were carried out on a Spectra Max 250 microplate reader (Molecular Devices Co., Sunnydale, CA).

Plasma urea was determined with a Urea L3K Assay from Genzyme Diagnostics (Cambridge, MA) and absorption was determined with an Ultrospec 3000 spectrophotometer (Pharmacia Biotech, London, UK). Plasma glucose was determined with the GLU Roche/ Hitachi kit (Roche Diagnostics, Indianapolis, IN) according to the manufacturer's protocol, which was modified to accommodate a 96-well microplate (Loiselle et al., 2009). Plasma NEFA was determined with the NEFA-HR(2) kit (Wako, Richmond, VA) using the manufacturer's protocol with the following modifications (Loiselle et al., 2009). Two hundred microliters of reagent $\mathrm{A}$ was added to $5 \mu \mathrm{L}$ of the plasma sample in a 96 -well microplate. The microplate was incubated at $37^{\circ} \mathrm{C}$ for $5 \mathrm{~min}$. The absorbance was read at $550 \mathrm{~nm}$ (reading A) on a Spectra Max 250 microplate reader. Then, $100 \mu \mathrm{L}$ of reagent $\mathrm{B}$ was added and the microplate was incubated at $37^{\circ} \mathrm{C}$ for $7 \mathrm{~min}$. The microplate was kept at room temperature $\left(\sim 23^{\circ} \mathrm{C}\right)$ for $11 \mathrm{~min}$, and the absorbance was read at $550 \mathrm{~nm}$ (reading B). Reading $\mathrm{A}$ was subtracted from reading $\mathrm{B}$ to remove the background.

\section{Hormone and Protein Assays}

Serum cortisol was determined by R\&D Systems Inc. Cortisol Assay (Minneapolis, MN). Serum haptoglobin was determined with a Bovine Haptoglobin ELISA test kit (Life Diagnostics Inc., West Chester, PA).

\section{Isolation of Peripheral Blood Mononuclear Cells and PMNL}

Peripheral blood mononuclear cells (PBMC) were isolated from 2 healthy cows in mid lactation as described by Loiselle et al. (2009), except that the cells were resuspended in $3 \mathrm{~mL}$ of sterile RPMI medium. The viable cells were counted with an automated cell counter (Countess Cell Counter, Invitrogen, Grand Island, NY). The PMNL were isolated from 3 healthy cows in mid lactation as described by Ster et al. (2012) and counted with the same automated cell counter.

\section{Proliferation of PBMC and Cytokine Production}

To measure the effect of treatments on PBMC proliferation and cytokine production, PMBC collected from healthy cows in mid lactation were resuspended in RPMI containing $1 \times$ antibiotic-antimycotic and $5 \%$ of the serum to be tested (d 2, 5, and 61 for each cow). This assay was performed 3 times in duplicate for each serum and for 2 different PBMC donors.

The proliferation of PBMC was determined as described by Loiselle et al. (2009), except that $1 \mu M$ carboxyfluorescein diacetate succinimidyl ester (CFDASE, a cell-permeable dye) was used. The volume of RPMI (mL) was equal to the number of wells. The cells were placed in the wells of a 12-well plate (BD Biosciences, Mississauga, ON, Canada) at $3 \times 10^{6}$ cells per well . Concanavalin A (ConA; from Canavalia ensiformis, Sigma-Aldrich Inc.) was added to 2 wells at a final concentration of $1 \mu \mathrm{g} / \mathrm{mL}$. The control well contained PBMC without ConA. De-complemented serum (150 $\mu \mathrm{L}$ ) from experimental cows was then added to each well. To complete the mixture, $1.85 \mathrm{~mL}$ of preheated $\left(37^{\circ} \mathrm{C}\right)$ RPMI (with antibiotic and L-glutamine) was added to each well. The plate was incubated for $3.5 \mathrm{~d}$ at $37^{\circ} \mathrm{C}$ in a $5 \% \mathrm{CO}_{2}$ atmosphere. After the first $20 \mathrm{~h}$, $1 \mathrm{~mL}$ of supernatant was taken from each well and frozen for IL-4 and IFN- $\gamma$ assays (Bovine IFN $\gamma$ Screening Set and Bovine IL-4 Screening Set, Thermo Scientific, Waltham, MA). After the full $3.5 \mathrm{~d}$, the cells were centrifuged for 5 min at $300 \times g$. The supernatant was discarded and the cells were resuspended in $500 \mu \mathrm{L}$ of $4 \%$ formaldehyde. The cells were left in the dark at room temperature for $15 \mathrm{~min}$. The proliferation of PBMC was analyzed by flow cytometry on a Coulter Epics XLMCL flow cytometer (Beckman Coulter, Brea, CA).

\section{Phagocytosis Assays}

To measure phagocytosis, PMNL collected from healthy cows in mid lactation were resuspended in RPMI containing $1 \times$ antibiotic-antimycotic and $5 \%$ of the serum to be tested (d 2, 5, and 61 for each cow). Opsonized Fluoresbrite microspheres (Polysciences Inc., Warrington, PA) were added to the PMNL. The phagocytosis assay was conducted as described by Ster et al. (2012). Fluorescence was determined with a BD FACSCanto II flow cytometer (BD Biosciences). This 
assay was performed in duplicate for each serum for 2 different PMNL donors.

\section{Chemotaxis Assays}

To measure chemotaxis, PMNL collected from healthy cows in mid lactation were resuspended in RPMI containing $1 \times$ antibiotic-antimycotic and $5 \%$ of the serum to be tested (d 2, 5, and 61 for each cow). A micropore Transwell Permeable Support (Corning Life Sciences, Corning, NY) was used to assess the chemotaxis of PMNL cells, and zymosan-activated bovine serum was used as chemoattractant. The assay was conducted as described by Ster et al. (2012). The assay was performed in duplicate for each serum with 2 different PMNL donors.

\section{Statistical Analysis}

Data were analyzed as repeated measurements using the MIXED procedure (SAS Institute Inc., Cary, NC). Time was used as the repeated effect and cow as the subject. For production of milk and ECM, previous lactation milk production was used as a covariate. Preplanned orthogonal contrasts were used to compare the CON with the partially milked (INC + NUR) treatments and the INC treatment with the NUR treatment. The Tukey's adjusted test was used for other treatment comparisons. Somatic cell counts were $\log _{10}$ transformed before analysis. Energy-corrected milk was calculated using the following equation: $\mathrm{ECM}=12.55$ $\times$ fat $(\mathrm{kg} / \mathrm{d})+7.39 \times$ protein $(\mathrm{kg} / \mathrm{d})+0.2595 \times$ milk $(\mathrm{kg} / \mathrm{d})$. The relationship between observed immune measures and the concentration of metabolites and hormones was evaluated using the CORR procedure of SAS. Differences were considered statistically significant when $P<0.05$.

\section{RESULTS}

\section{Milk Production, Milk Composition, DMI, and Water Intake}

During the first $5 \mathrm{~d}$ of lactation, the amount of milk harvested averaged $27.3 \pm 1.46$ and $9.7 \pm 1.40 \mathrm{~kg} / \mathrm{d}$ for $\mathrm{CON}$ and INC treatments, respectively (Figure 1, panel A). For the NUR treatment, no milk was mechanically harvested on $\mathrm{d} 1$ and 2, and milk yield averaged $16.7 \pm$ $1.15 \mathrm{~kg} / \mathrm{d}$ between $\mathrm{d} 3$ and 5 . Milk fat percentage was greater for $\mathrm{CON}$ than for partially milked treatments $(P<0.001)$ and greater for NUR than for INC $(P$ $<0.01$; data not shown). Milk protein percentage was greater $(P<0.01)$ for INC $(5.06 \pm 0.08 \%)$ and NUR
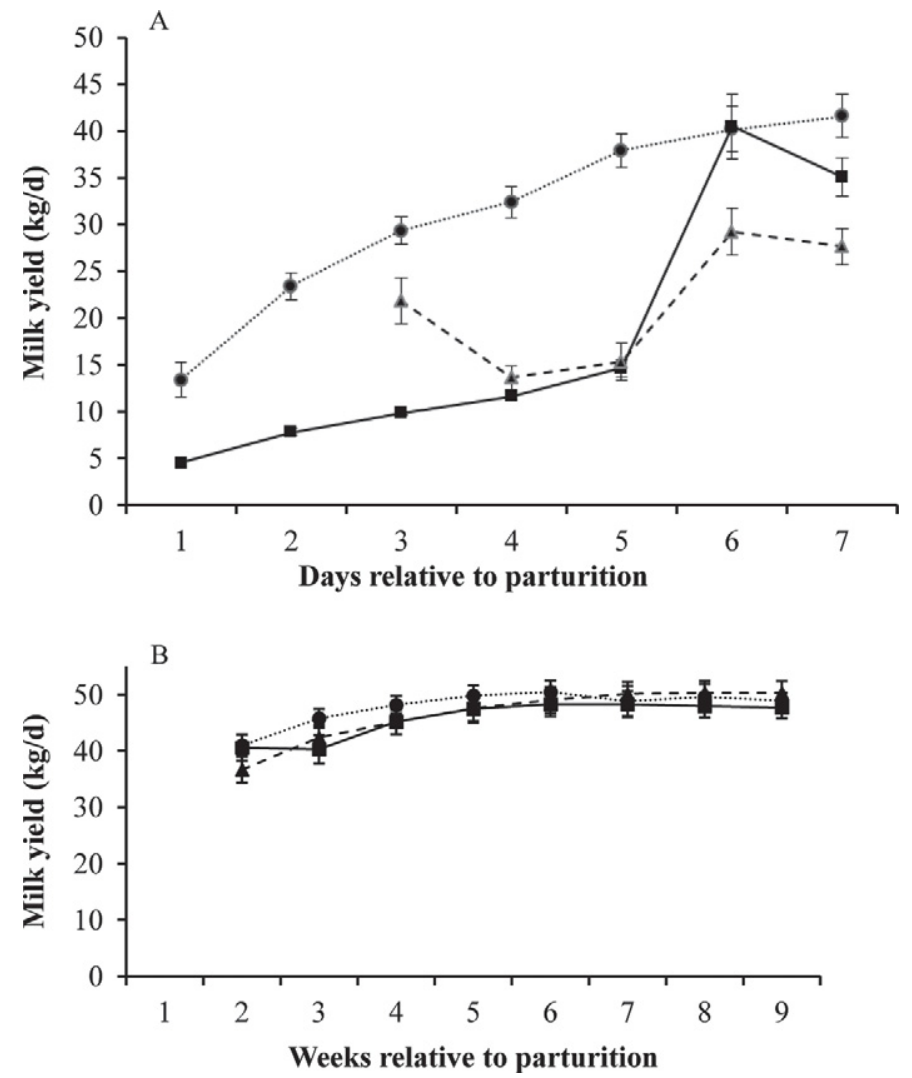

Figure 1. Effect of milking management on milk yield during (A) the first week of lactation and (B) over the first 9 wk of lactation. $=$ control cows (milked completely twice daily throughout lactation); - = incompletely milked cows (incompletely milked twice daily during the first $5 \mathrm{~d}$ of lactation and then completely milked twice daily throughout lactation); $\boldsymbol{\Delta}=$ nursed cows (left with their calves and milked once daily on d 3,4 , and 5 for the first $5 \mathrm{~d}$ and then completely milked twice daily throughout lactation). Data are presented as least squares means \pm SEM.

$(5.52 \pm 0.08 \%)$ than for CON $(3.99 \pm 0.16 \%)$. Treatment had no effect on milk lactose percentage or SCC.

Milk production of the cows from INC and NUR rapidly recovered to that of $\mathrm{CON}$ cows when twicedaily milking was implemented for all cows (Figure 1, panel B). We observed no residual effect of treatment on milk production $(P>0.25)$, which averaged $47.8 \pm$ $0.72,45.7 \pm 0.83$, and $46.4 \pm 0.87 \mathrm{~kg} / \mathrm{d}$, respectively, between wk 2 and 9 for CON, INC, and NUR treatments, respectively.

The percentage $(P=0.06)$ and yield $(P=0.08)$ of milk fat tended to be greater for CON than for the partial treatments (Table 1). These effects were more obvious in early lactation and were significant $(P<$ $0.05)$ in wk 2 and 3. Milk protein percentage was greater $(P<0.01)$ for partial treatments than for $\mathrm{CON}$ in wk 2 but was similar for the rest of the posttreatment period (Table 1). Protein yield, protein percentage, and 
Table 1. Mean milk composition values, SCC, and feed and water intakes between wk 2 and 9 for cows milked completely (control) or incompletely, or left with their calves and milked once daily on $\mathrm{d} 3,4$, and 5 (nursing) during the first $5 \mathrm{~d}$ of lactation

\begin{tabular}{|c|c|c|c|c|c|c|c|}
\hline Item & \multicolumn{3}{|c|}{ Treatment $(\mathrm{T})$} & $\mathrm{SEM}^{1}$ & \multicolumn{3}{|c|}{$P$-value } \\
\hline Milk fat $(\mathrm{kg} / \mathrm{d})$ & 2.46 & 2.27 & 2.16 & 0.11 & 0.15 & 0.08 & 0.45 \\
\hline Milk protein (\%) & 3.04 & 3.09 & 3.24 & 0.06 & 0.08 & 0.12 & 0.10 \\
\hline Milk protein $(\mathrm{kg} / \mathrm{d})$ & 1.46 & 1.40 & 1.49 & 0.0719 & 0.55 & 0.87 & 0.28 \\
\hline Milk lactose (\%) & 4.51 & 4.56 & 4.55 & 0.02 & 0.46 & 0.22 & 0.85 \\
\hline DMI $(\mathrm{kg} / \mathrm{d})$ & 20.5 & 20.7 & 21.2 & 0.6 & 0.70 & 0.57 & 0.54 \\
\hline Water intake $(\mathrm{L} / \mathrm{d})$ & 113 & 109 & 110 & 3.3 & 0.55 & 0.29 & 0.78 \\
\hline
\end{tabular}

${ }^{1}$ Standard error of the LSM.

${ }^{2}$ For SCC, statistical analysis was performed on $\log _{10}$ transformed values.

lactose yield were not affected by treatment during the posttreatment period (Table 1). Posttreatment ECM was similar among treatments, averaging $52.9 \pm 0.89$, $49.7 \pm 0.95$, and $49.2 \pm 1.07 \mathrm{~kg} / \mathrm{d}$ for CON, INC, and NUR treatments, respectively. Somatic cell count was greater for $\mathrm{CON}$ cows than for those partially milked $(P<0.05)$.

Treatments did not affect DMI or water intake during (data not shown) or after (Table 1) the treatment period. Between d 2 and 61, BW decreased $(P<0.001)$ in all treatments; however, no differences were found between treatments (data not shown).

\section{Blood Composition}

During the treatment period, glucose concentration was greater for partially milked cows than for CON cows $(P<0.0001$; Figure 2, panel A). This effect persisted after twice-daily milking resumed until d $21(P$ $<0.05$ ). The concentration of NEFA was greater for CON cows than for partially milked cows $(P<0.05)$ during the treatment period, but no residual effect was found during the posttreatment period (Figure 2, panel B). The concentration of BHBA was also greater for CON cows than for partially milked cows during the treatment period $(P<0.0001)$ and until d 21 of the posttreatment period $(P<0.01$; Figure 2 , panel C). The concentration of phosphorus was greater for partially milked cows than for CON cows $(P<0.05$; Figure 3, panel A). On d 5, the phosphorus concentration was greater for cows in the INC treatment than for cows in the NUR treatment $(P<0.01)$. Phosphorus concentration was similar for all treatments during the posttreatment period. Cortisol concentrations tended to be lower $(P=0.08)$ for CON cows than for partially milked cows during the treatment period and tended $(P=0.06)$ to be lower for cows in the NUR treatment than in the INC treatment on d 14 (Figure 3, panel B).
Urea and haptoglobin concentrations were not affected by treatment during or after the treatment period $(P>$ 0.1 ; data not shown).

\section{Immunological Parameters}

White blood cell populations were determined 2, 5 , and $61 \mathrm{~d}$ after calving (Table 2). The percentage of PMNL decreased from d 2 to $5(P<0.001)$ and increased from d 5 to $61(P<0.01)$. The percentage of PMNL was lower in CON cows than in partially milked cows $(P<0.05)$. However, the percentage of lymphocytes increased from d 2 to $5(P<0.001)$, and was greater in CON cows than in partially milked cows $(P<0.05)$.

Peripheral blood mononuclear cells were incubated with serum obtained from experimental cows on d 2, 5, and 61 postcalving. Proliferation of ConA-stimulated cells increased with DIM (Figure 4, panel A; $P<0.001$ ) and a time $\times$ treatment interaction $(P<0.001)$ was observed. Treatment had no effect on d 2 , but proliferation tended $(P=0.07)$ to be greater for cells incubated in serum from cows in the INC treatment than from cows in the NUR treatment. Proliferation was lower $(P<0.01)$ for PBMC incubated with d 61 sera from cows in the INC treatment than from cows in the CON or NUR treatment. Production of IL- 4 by PBMC increased with DIM (Figure 4, panel B; $P<0.001$ ), but was not affected by treatment $(P>0.1)$. Production of IFN- $\gamma$ was not affected by DIM or treatment $(P>0.1$; data not shown).

Chemotaxis and phagocytosis were evaluated using PMNL incubated for $2 \mathrm{~h}$ with serum obtained from experimental cows on $\mathrm{d} 2,5$, and 61 postcalving. We observed no effect of DIM or treatments on the proportion of cells that migrated ( $P>0.1$; data not shown). Phagocytic activity was evaluated as the percentage of phagocytic neutrophils. In this assay, phagocytosis 
Table 2. Blood cell populations on d 2, 5, and 61 for cows milked completely (Control) or incompletely, or left with their calves and milked once daily on $\mathrm{d} 3,4$, and 5 (nursing) during the first $5 \mathrm{~d}$ of lactation

\begin{tabular}{|c|c|c|c|c|c|c|c|c|c|c|}
\hline Item & \multicolumn{3}{|c|}{ Control } & \multicolumn{3}{|c|}{ Incomplete } & \multicolumn{3}{|c|}{ Nursing } & $\mathrm{SEM}^{1}$ \\
\hline Total $\mathrm{WBC}^{2}$ & 8.7 & 8.2 & 8.4 & 9.1 & 8.3 & 8.7 & 8.8 & 8.4 & 8.4 & 0.55 \\
\hline Lymphocytes (\%) & 44.1 & 54.2 & 51.2 & 42.0 & 49.1 & 47.3 & 40.4 & 46.4 & 44.5 & 2.6 \\
\hline
\end{tabular}

${ }^{1}$ Standard error of the LSM.

${ }^{2}$ Total white blood cells $\left(\times 10^{9} / \mathrm{L}\right)$.

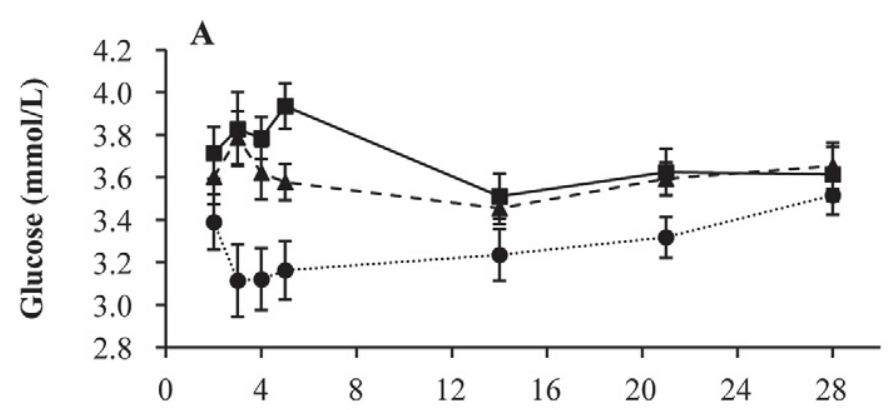

intensity corresponds to the quantity of ingested fluorospheres, and the phagocytic index is the combination of the 2 variables. No effects of DIM or treatments were observed $(P>0.1)$ for the 3 measures (data not shown).

The relationship between metabolite concentrations and immune cell functions was evaluated. The strongest relationships were the negative correlations between serum NEFA content and PBMC proliferation $(\mathrm{r}=-0.66, P<0.001)$ and IL-4 secretion $(\mathrm{r}=-0.44$, $P<0.001)$. Serum BHBA was weakly correlated with PBMC proliferation $(\mathrm{r}=-0.28, P<0.001)$. When
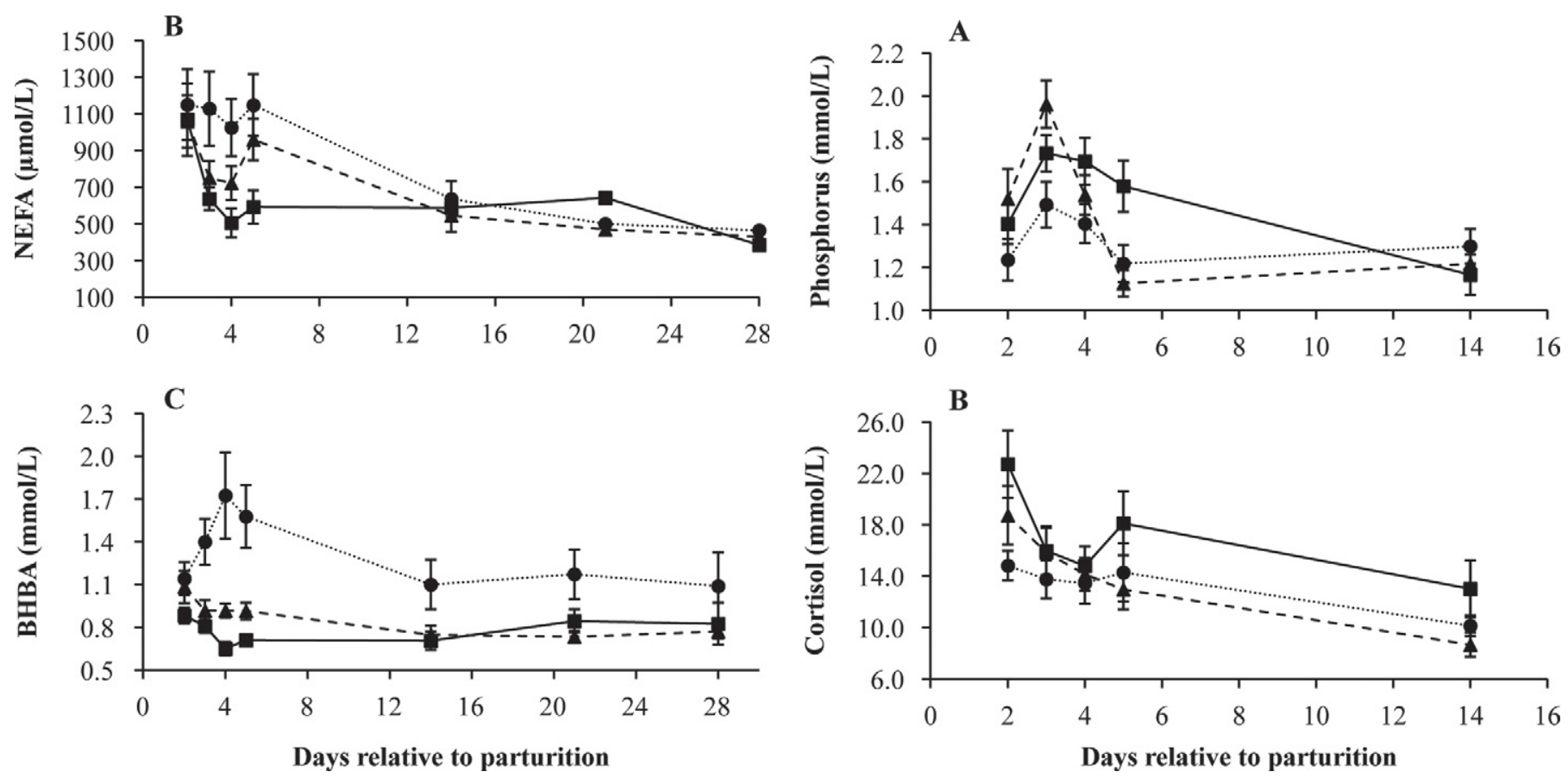

Figure 2. Effect of milking management during the first $5 \mathrm{~d}$ of lactation on (A) glucose, (B) NEFA, and (C) BHBA concentrations in relation to the days around parturition. $\bullet=$ control cows (milked completely twice daily throughout lactation); $\mathbf{\square}=$ incompletely milked cows (incompletely milked twice daily during the first $5 \mathrm{~d}$ of lactation and then completely milked twice daily throughout lactation); $\boldsymbol{\Delta}=$ nursed cows (left with their calves and milked once daily on d 3,4, and 5 for the first $5 \mathrm{~d}$ and then completely milked twice daily throughout lactation). Data are presented as least squares means \pm SEM.

Figure 3. Effect of milking management during the first $5 \mathrm{~d}$ of lactation on (A) phosphorus and (B) cortisol concentrations in relation to the days around parturition. $\bullet=$ control cows (milked completely twice daily throughout lactation); $\mathbf{\square}=$ incompletely milked cows (incompletely milked twice daily during the first $5 \mathrm{~d}$ of lactation and then completely milked twice daily throughout lactation); $\boldsymbol{\Delta}=$ nursed cows (left with their calves and milked once daily on d 3, 4, and 5 for the first $5 \mathrm{~d}$ and then completely milked twice daily throughout lactation). Data are presented as least squares means \pm SEM. 
A
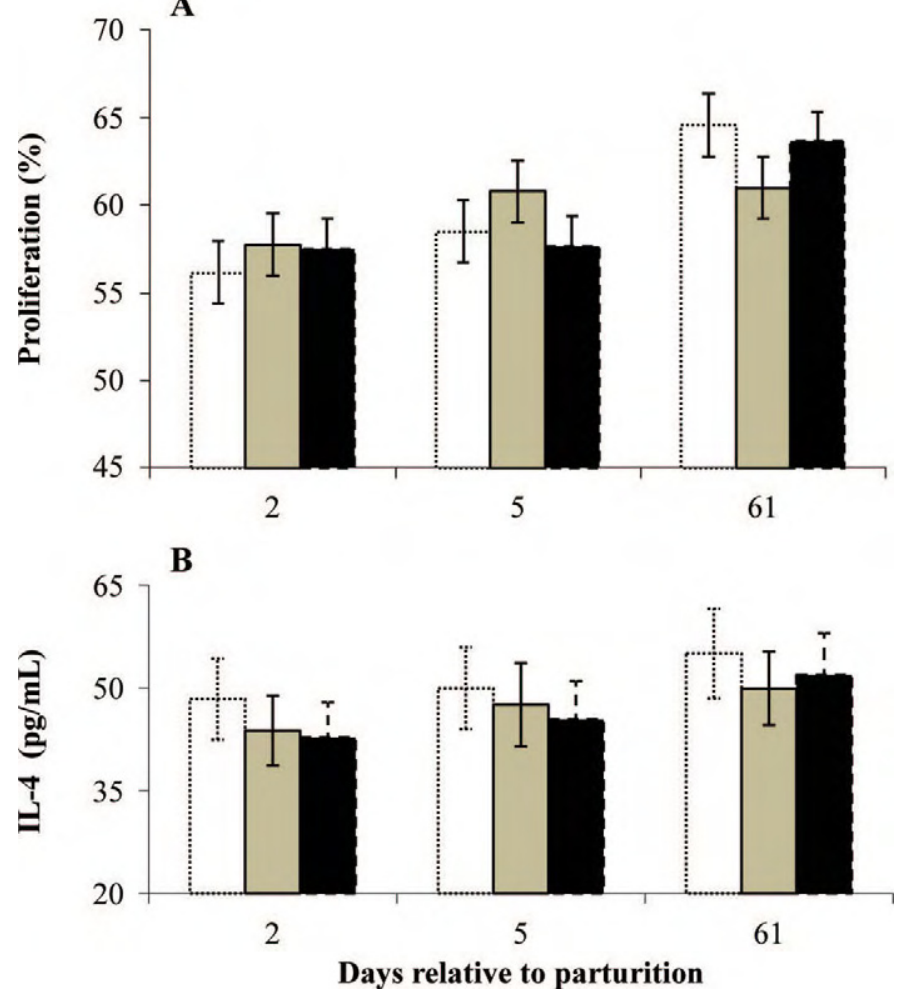

Figure 4. Effect of milking management during the first $5 \mathrm{~d}$ of lactation on (A) concanavalin A-stimulated peripheral blood mononuclear cell proliferation and (B) production of IL-4 in relation to the days around parturition. White = cows completely milked twice daily throughout lactation; gray $=$ cows partially milked twice daily during the first $5 \mathrm{~d}$ of lactation and then completely milked twice daily throughout lactation; black $=$ cows left with their calves and milked once daily on $\mathrm{d} 3,4$, and 5 for the first $5 \mathrm{~d}$ and then completely milked twice daily throughout lactation. Data are presented as least squares means \pm SEM. Color version available in the online PDF.

correlations were calculated within sampling days, correlations between serum NEFA content and PBMC proliferation and IL-4 secretion were highly significant $(P<0.001)$ for $\mathrm{d} 2$ and 5 but were no longer significant at $\mathrm{d} 61$.

\section{DISCUSSION}

This study evaluated the effect of decreasing the amount of milk harvested during the first $5 \mathrm{~d}$ of lactation on milk production, blood metabolites, and immunological parameters in multiparous dairy cows. The quantity of milk harvested during this period from the cows in the INC treatment represented about $35 \%$ of that from the CON cows. In the NUR treatment, the amount of milk consumed by the calves was not recorded. However, a previous study indicated that Holstein calves allowed to suckle twice a day drank 6.5 $\mathrm{kg} / \mathrm{d}$ of milk during their first week of life (de Passillé et al., 2008). Using this estimate, the amount of milk harvested from cows in the NUR treatment represented approximately $35 \%$ of that of CON cows for $\mathrm{d} 1$ and 2 , and $75 \%$ for $\mathrm{d} 3,4$, and 5 .

Our first hypothesis was that a decrease in milk harvested in early lactation would not have a detrimental effect on posttreatment milk production if milking stimulation were maintained. Reducing milk production by milking once a day for 1 (Loiselle et al., 2009) or 3 (Rémond et al., 1999) wk postpartum also reduced milk production during the weeks following the return to twice-daily milking. Accordingly, increasing the milking frequency in early lactation resulted in increases in milk production that persisted beyond the treatment period (Bar-Peled et al., 1995; Hale et al., 2003; Wall et al., 2006). In the present experiment, when complete milking (twice a day) was resumed, milk production of the cows in the partial treatment group caught up rapidly with milk production of the cows in the CON group. This suggests that the number of milking events was more important than the amount of milk removed. Wall et al. (2006) reported that it is possible to mimic the effect of milking 4 times a day in early lactation by combining twice-daily milking with intravenous injections of PRL twice a day. In our study, twice-a-day incomplete machine milking or frequent suckling by the calves maintained frequent mammary stimulation and, presumably, PRL release. This indicates that short-term reduction of milk harvest may be used without compromising subsequent milk production if it is coupled to a strategy that ensures adequate milking stimulation.

Our second hypothesis was that reducing the amount of milk harvested in early lactation would decrease the metabolic disturbances that occur after calving. In our study, the reduction in milk harvested during the first $5 \mathrm{~d}$ of lactation led to a decrease in NEFA and BHBA concentrations in the blood, thereby minimizing the postpartum hypoglycemia typically observed in highyielding cows (Patton et al., 2006; Loiselle et al., 2009). Reciprocally, an increase in milking frequency in early lactation has been reported to accentuate metabolic imbalances (Andersen et al., 2004; Fernandez et al., 2004). Blood NEFA concentration reflects the degree of lipid mobilization and is a sign of negative energy balance (Bauman and Currie, 1980; Ingvartsen and Andersen, 2000; Drackley et al., 2005). In early lactation, the quantity of NEFA taken up by the liver increases with increased quantities of NEFA in the blood (Reynolds et al., 2003). When the liver's capacity to oxidize or export fatty acids is overwhelmed, triglycerides may accumulate in the liver, impairing its function (fatty liver syndrome; Bobe et al., 2004). If insufficient carbohydrates are available, some acetyl-coenzyme A will be converted to acetoacetate and $\beta$-hydroxybutyrate. The 
accumulation of these ketone bodies in the blood impairs gluconeogenesis, resulting in hypoglycemia. Based on the use of BHBA as a ketosis indicator (Peek and Divers, 2008), in our study, $47 \%(7 / 15), 6 \%(1 / 16)$, and $6 \%(1 / 16)$ of cows met the criteria for clinical ketosis and $13 \%(2 / 15), 6 \%(1 / 16)$, and $13 \%(2 / 16)$ of cows met the criteria for subclinical ketosis in the CON, INC, and NUR treatments, respectively. Therefore, it appears that decreasing the amount of milk harvested in early lactation leads to a more positive energy balance, which contributes to a reduction in the incidence of metabolic disease.

After parturition, the large amounts of calcium and phosphorus needed for milk synthesis result in a transient (a few days) reduction of their concentrations in the blood (Harris et al., 1990; Horst et al., 1997). Loiselle et al. (2009) reported slightly higher serum concentrations of phosphorus and calcium in cows milked once daily during the first week of lactation than in cows milked twice a day from calving. In our study, phosphorus concentration was greater in partially milked cows than in CON cows. Serum concentrations of calcium were not reported because most cows received a subcutaneous injection of calcium to prevent milk fever. Nevertheless, mobilization of both Ca and $\mathrm{P}$ from bone to increase plasma $\mathrm{Ca}$ and $\mathrm{P}$ is regulated by 1,25-dihydroxyvitamin $\mathrm{D}$ and parathyroid hormone (Horst, 1986). A larger study is needed to determine whether reducing the amount of milk harvested can reduce the incidence of milk fever.

During the periparturient period, the dairy cow experiences a natural state of immunosuppression, which is associated with high susceptibility to infectious diseases (Mallard et al., 1998; Kehrli and Harp, 2001). In mastectomized cows, the number of immune cells and their associated functions did not provide clear evidence that calving itself causes immunosuppression (Kimura et al., 1999, 2002; Nonnecke et al., 2003). However, PBMC proliferation and secretion of IL-4 decreased in response to incubation with early postpartum sera, which points to immunosuppression around parturition. The causes of this immunosuppression are not completely understood, but Ster et al. (2012) found a negative correlation between serum NEFA concentrations and PBMC proliferation. Accordingly, Ster et al. (2012) observed that serum harvested at 61 DIM but supplemented with enough NEFA to reach the level present in serum harvested at 5 DIM resulted in PBMC proliferation similar to that obtained with the latter serum. In addition, Lacetera et al. (2002) showed that NEFA concentrations greater than $250 \mu M$ inhibited ConA-induced proliferation of ovine PBMC. Similarly, a negative correlation between NEFA concentration and PBMC proliferation was observed in the current study. However, we only found a trend toward greater proliferation with INC serum compared with NUR serum at $d 5$. This is probably attributable to the fact that blood NEFA concentrations were high in all treatments at d 2 and were similar for NUR and CON cows at $\mathrm{d} 5$. The lower level of proliferation observed at d 61 for incompletely milked cows was not related to the serum NEFA concentration because proliferation was not found to be correlated with NEFA when only d 61 data were considered.

In our study, immune functions evaluated for PMNL (chemotaxis and phagocytosis) were not depressed around calving and were not affected by treatments. Similarly, Ster et al. (2012) were unable to show postpartum depression of PMNL functions. Nevertheless, they reported that NEFA inhibited oxidative burst at concentrations greater than $500 \mu M$. Such a concentration is too high to be reached by serum samples diluted at the $5 \%$ level. Some studies have reported that PMNL chemotaxis (Nagahata et al., 1988; Kehrli et al., 1989a) and phagocytosis (Kehrli et al., 1989a; Llamas Moya et al., 2008; Silvestre et al., 2011) are impaired during the transition period. In those studies, assays were conducted on PMNL harvested from the experimental animals. During the transition period, reproductive tract demand for PMNL increases, resulting in a rapid mobilization of bone marrow PMNL and an increase in the proportion of immature PMNL in the blood (Kehrli et al., 1989a). This high proportion of immature cells has been linked to a reduced ability to phagocytize bacteria (Moyes et al., 2009). Similarly, impairment of neutrophil function has been reported in periparturient cows diagnosed with metritis but not in those with normal uterine health (Hammon et al., 2006). The effect of cell maturity could not be tested in our model, because PMNL were isolated from midto late-lactation cows. Nevertheless, the percentage of PMNL decreased during the first $5 \mathrm{~d}$ of lactation and the percentage of neutrophils was lower for CON than for partial (INC + NUR) treatments in our experiment.

Both methods used to implement partial milking led to changes in the routine management of the cows, particularly in the NUR treatment. All calves required suckling assistance, especially when the dam had an unfavorable udder conformation or when the calves were weak. In addition, the most common mechanism of transmission of Mycobacterium avium ssp. paratuberculosis to calves is the ingestion of bacteria shed by an infected adult animal (Peek and Divers, 2008). Therefore, leaving the calf with its dam for several days would increase the risk of transmission of Johne's disease in herds where the disease is present. Consequently, incomplete mechanical milking of postpartum cows is probably a better option than letting cows nurse the 
calves. Nevertheless, incomplete milking requires attention from the milker, especially in the absence of a milk meter.

\section{CONCLUSIONS}

The transition period is marked by metabolic and immunological changes that have an important effect on the health of dairy cattle. These changes are directly linked to the synthesis of milk and initiation of milk production. In nature, the quantity of milk needed for offspring increases over time but is relatively low during the newborn's first days of life. This explains the gradual transition from the dry period to a situation of high milk demand; the lesser quantity of milk required by the newborn initially probably also helps to reduce the magnitude of the negative energy balance. In this experiment, we tested 2 approaches for limiting milk production. Both approaches were successful at limiting metabolic imbalances in early lactation while maintaining sufficient milking stimulation to sustain subsequent milk production. Although the study did not show a clear-cut improvement in immune status, the negative correlation between NEFA concentration and lymphocyte functions suggests that improved energy status in early lactation may have a positive effect on the immune responses of dairy cows. Larger studies are needed to determine whether the positive effects of limiting postpartum milk output will lead to lower disease incidence.

\section{ACKNOWLEDGMENTS}

This research was financially supported by the Dairy Farmers of Canada (Ottawa, ON) and Agriculture and Agri-Food Canada (Ottawa, ON). The authors thank Nelson Dinn, Barry Thompson, Bill Kramer, Brad Duncan, Mike Duncan, Ted Toenders, Dan Peters, Marianne Villetaz-Robichaud, Catherine Gagnon, Marie-France Hurteau and Jean-Philippe Parent for their help in conducting the experiment in Agassiz. We also thank Lisette St-James, Philippe Bernier-Dodier, Séverine Ollier, Céline Ster, Julie Côté-Gravel, Kathy Doyon, and Sara Gandy for their help in conducting the laboratory analyses at the Dairy and Swine R\&D Centre in Sherbrooke.

\section{REFERENCES}

Andersen, J. B., N. C. Friggens, T. Larsen, M. Vestergaard, and K. L. Ingvartsen. 2004. Effect of energy density in the diet and milking frequency on plasma metabolites and hormones in early lactation dairy cows. J. Vet. Med. A Physiol. Pathol. Clin. Med. 51:52-57.

Bar-Peled, U., E. Maltz, I. Bruckental, Y. Folman, Y. Kali, H. Gacitua, A. R. Lehrer, C. H. Knight, B. Robinzon, H. Voet, and H.
Tagari. 1995. Relationship between frequent milking or suckling in early lactation and milk production of high producing dairy cows. J. Dairy Sci. 78:2726-2736.

Bauman, D. E., and B. W. Currie. 1980. Partitioning of nutrients during pregnancy and lactation: A review of mechanisms involving homeostasis and homeorhesis. J. Dairy Sci. 63:1514-1529.

Bobe, G., J. W. Young, and D. C. Beitz. 2004. Invited review: Pathology, etiology, prevention, and treatment of fatty liver in dairy cows. J. Dairy Sci. 87:3105-3124.

Busato, A., D. Faissler, U. Küpfer, and J. W. Blum. 2002. Body condition scores in dairy cows: Associations with metabolic and endocrine changes in healthy dairy cows. J. Vet. Med. A Physiol. Pathol. Clin. Med. 49:455-460.

CCAC (Canadian Council on Animal Care). 1993. Guidelines to the Care and Use of Experimental Animals. Vol. I. 2nd ed. E. D. Olfert, B. M. Cross, and A. A. McWilliam, ed. CCAC, Ottawa, Ontario, Canada.

Chapinal, N., D. M. Veira, D. M. Weary, and M. A. G. von Keyserlingk. 2007. Technical note: Validation of a system for monitoring individual feeding and drinking behavior and intake in grouphoused cattle. J. Dairy Sci. 90:5732-5736.

Daniel, R. C. W. 1983. Motility of the rumen and abomasum during hypocalcaemia. Can. J. Comp. Med. 47:279-280.

de Passillé, A. M., P. G. Marnet, H. Lapierre, and J. Rushen. 2008. Effects of twice-daily nursing on milk ejection and milk yield during nursing and milking in dairy cows. J. Dairy Sci. 91:1416-1422.

Drackley, J. K. 1999. Biology of dairy cows during the transition period: The final frontier? J. Dairy Sci. 82:2259-2273.

Drackley, J. K., H. M. Dann, G. N. Douglas, N. A. Janovick Guretzky, N. B. Litherland, J. P. Underwood, and J. J. Loor. 2005. Physiological and pathological adaptations in dairy cows that may increase susceptibility to periparturient diseases and disorders. Ital. J. Anim. Sci. 4:323-344.

Fernandez, J., C. M. Ryan, D. M. Galton, and T. R. Overton. 2004 Effect of milking frequency during early lactation on performance and health of dairy cows. J. Dairy Sci. 82(Suppl. 1):424. (Abstr.)

Goff, J. P., and R. L. Horst. 1997. Physiological changes at parturition and their relationship to metabolic disorders. J. Dairy Sci. 80:1260-1268

Gorewit, R. C., K. Svennersten, W. R. Butler, and K. Uvnäs-Moberg. 1992. Endocrine responses in cows milked by hand and machine. J. Dairy Sci. 75:443-448.

Hale, S. A., A. V. Capuco, and R. A. Erdman. 2003. Milk yield and mammary growth effects due to increased milking frequency during early lactation. J. Dairy Sci. 86:2061-2071.

Hammon, D. S., I. M. Evjen, T. R. Dhiman, J. P. Goff, and J. L. Walters. 2006. Neutrophil function and energy status in Holstein cows with uterine health disorders. Vet. Immunol. Immunopathol. 113:21-29.

Harris, B., D. Morse Jr., H. H. Head, and H. H. Van Horn. 1990. Phosphorus nutrition and excretion by dairy animals. Circular no. 849 . University of Florida, Institute of Food and Agricultural Sciences (IFAS), Cooperative Extension Service, Gainesville.

Horst, R. L. 1986. Regulation of calcium and phosphorus homeostasis in the dairy cow. J. Dairy Sci. 69:604-616.

Horst, R. L., J. P. Goff, T. A. Reinhardt, and D. R. Buxton. 1997. Strategies for preventing milk fever in dairy cattle. J. Dairy Sci. 80:1269-1280.

Ingvartsen, K. L., and J. B. Andersen. 2000. Integration of metabolism and intake regulation: A review focusing on periparturient animals. J. Dairy Sci. 83:1573-1597.

Kehrli, M. E., Jr., and J. A. Harp. 2001. Immunity of the mammary gland. Vet. Clin. North Am. Food Anim. Pract. 17:495-516.

Kehrli, M. E., Jr., B. J. Nonnecke, and J. A. Roth. 1989a. Alterations in bovine neutrophil function during the periparturient period. Am. J. Vet. Res. 50:207-214.

Kehrli, M. E., Jr., B. J. Nonnecke, and J. A. Roth. 1989b. Alterations in bovine lymphocyte function during the periparturient period. Am. J. Vet. Res. 50:215-220.

Kimura, K., J. P. Goff, and M. E. Kehrli Jr. 1999. Effects of the presence of the mammary gland on expression of neutrophil adhesion 
molecules and myeloperoxidase activity in periparturient dairy cows. J. Dairy Sci. 82:2385-2392.

Kimura, K., J. P. Goff, M. E. Kehrli Jr., J. A. Harp, and B. J. Nonnecke. 2002. Effects of mastectomy on composition of peripheral blood mononuclear cell populations in periparturient dairy cows. J. Dairy Sci. 85:1437-1444.

Koprowski, J. A., and H. A. Tucker. 1973. Serum prolactin during various physiological states and its relationship to milk production in the bovine. Endocrinology 92:1480-1487.

Krohn, C. C. 2001. Effects of different suckling systems on milk production, udder health, reproduction, calf growth and some behavioural aspects in high producing dairy cows: A review. Appl. Anim. Behav. Sci. 72:271-280.

Lacasse, P., V. Lollivier, R. M. Bruckmaier, Y. R. Boisclair, G. W. Wagner, and M. Boutinaud. 2011. Effect of the prolactin-release inhibitor quinagolide on lactating dairy cows. J. Dairy Sci. 94:1302-1309.

Lacetera, N., O. Franci, D. Scalia, U. Bernabucci, B. Ronchi, and A. Nardone. 2002. Effects on functions of ovine blood mononuclear cells for each of several fatty acids at concentrations found in plasma of healthy and ketotic ewes. Am. J. Vet. Res. 63:958-962.

LeBlanc, S. J., K. E. Leslie, and T. F. Duffield. 2005. Metabolic predictors of displaced abomasum in dairy cattle. J. Dairy Sci. $88: 159-170$.

Llamas Moya, S., M. A. Gomez, L. A. Boyle, J. F. Mee, B. O'Brien, and S. Arkins. 2008. Effects of milking frequency on phagocytosis and oxidative burst activity of phagocytes from primiparous and multiparous dairy cows during early lactation. J. Dairy Sci. 91:587-595.

Loiselle, M. C., C. Ster, B. G. Talbot, X. Zhao, G. F. Wagner, Y. R. Boisclair, and P. Lacasse. 2009. Impact of postpartum milking frequency on the immune system and the blood metabolite concentration of dairy cows. J. Dairy Sci. 92:1900-1912.

Lupoli, B., B. Johansson, K. Uvnas-Moberg, and K. SvennerstenSjaunja. 2001. Effect of suckling on the release of oxytocin, prolactin, cortisol, gastrin, cholecytokinin, somatostatin and insulin in dairy cows and their calves. J. Dairy Res. 68:175-187.

Mallard, B. A., J. C. Dekkers, M. J. Ireland, K. E. Leslie, S. Sharif, C. Lacey Vankampen, L. Wagter, and B. N. Wilkie. 1998. Alteration in immune responsiveness during the peripartum period and its ramification on dairy cow and calf health. J. Dairy Sci. 81:585-595.
Moyes, K. M., J. K. Drackley, J. L. Salak-Johnson, D. E. Morin, J. C. Hope, and J. J. Loor. 2009. Dietary-induced negative energy balance has minimal effects on innate immunity during Streptococcus uberis mastitis challenge in dairy cows during mid lactation. J. Dairy Sci. 92:4301-4316.

Nagahata, H., S. Makino, S. Takeda, H. Takahashi, and H. Noda. 1988. Assessment of neutrophil function in the dairy cow during the perinatal period. Zentralbl. Veterinarmed. B 35:747-751.

Nonnecke, B. J., K. Kimura, J. P. Goff, and M. E. Kehrli Jr. 2003 Effects of the mammary gland on functional capacities of blood mononuclear leukocyte populations from periparturient cows. J. Dairy Sci. 86:2359-2368.

Patton, J., D. A. Kenny, J. F. Mee, F. P. O'Mara, D. C. Wathes, M. Cook, and J. J. Murphy. 2006. Effect of milking frequency and diet on milk production, energy balance, and reproduction in dairy cows. J. Dairy Sci. 89:1478-1487.

Peek, S. F., and T. J. Divers. 2008. Diseases of Dairy Cattle. 2nd ed. Elsevier Inc., Amsterdam, the Netherlands.

Rémond, B., J. B. Coulon, M. Nicloux, and D. Levieux. 1999. Effect of temporary once-daily milking in early lactation on milk production and nutritional status of dairy cows. Ann. Zootech. 49:341-352.

Reynolds, C. K., P. C. Aikman, B. Lupoli, D. J. Humphries, and D E. Beever. 2003. Splanchnic metabolism of dairy cows during the transition from late gestation through early lactation. J. Dairy Sci. 86:1201-1217.

Sheldon, I. M. 2004. The postpartum uterus. Vet. Clin. North Am. Food Anim. Pract. 20:569-591.

Silvestre, F. T., T. S. M. Carvalho, P. C. Crawford, J. E. P. Santos, C. R. Staples, T. Jenkins, and W. W. Thatcher. 2011. Effects of differential supplementation of fatty acids during the peripartum and breeding periods of Holstein cows: II. Neutrophil fatty acids and function, and acute phase proteins. J. Dairy Sci. 94:2285-2301.

Ster, C., M. C. Loiselle, and P. Lacasse. 2012. Effect of postcalving serum nonesterified fatty acids concentration on the functionality of bovine immune cells. J. Dairy Sci. 95:708-717.

Wall, E. H., H. M. Crawford, S. E. Ellis, G. E. Dahl, and T. B. McFadden. 2006. Mammary response to exogenous prolactin or frequent milking during early lactation in dairy cows. J. Dairy Sci. 89:4640-4648 